\title{
Contribution by different marine bacterial communities to particulate beam attenuation
}

\author{
Martin A. Montes-Hugo ${ }^{1, *}$, Hugh Ducklow ${ }^{2}$, Oscar M. Schofield ${ }^{1}$ \\ ${ }^{1}$ Coastal Ocean Observation, Institute of Marine and Coastal Sciences, Rutgers University, New Jersey 08901-8521, USA \\ ${ }^{2}$ The Ecosystems Center, Marine Biological Laboratory, Woods Hole, Massachusetts 02543, USA
}

\begin{abstract}
Contribution of heterotrophic marine bacteria (HB) to the particulate beam attenuation coefficient $\left(C_{\mathrm{p}}\right)$ was estimated as a function of latitude in diverse marine regions. Calculations were based on surface measurements ( 0 to $20 \mathrm{~m}$ depth) of bacterial abundance and biovolume, physiooptical empirical relationships, and light scattering models. Relative contribution of spherical HB to $C_{\mathrm{p}}\left(C_{\mathrm{HB}} / C_{\mathrm{p}}\right)$ was commonly below $10 \%$, and slightly increased $(\sim 3 \%)$ when bacterial shape was assumed to be cylindrical. HB accounted for a larger fraction of $C_{\mathrm{p}}$ magnitude at lower latitudes because of the greater abundance of bacteria. HB explained about a third of $C_{p}$ spatial variability in Antarctic (Antarctic Polar Front, Ross Sea) and non-polar (equatorial Pacific Ocean, Arabian Sea) oceanic regions.
\end{abstract}

KEY WORDS: Heterotrophic marine bacteria $\cdot$ Particulate beam attenuation coefficient $\cdot$ Light scattering $\cdot$ Mie theory $\cdot$ Polar environments

\section{INTRODUCTION}

Beam transmissometers are a common instrument on oceanographic cruises as several important biochemical parameters, e.g. particulate organic carbon (POC) (Bishop 1999, Behrenfeld \& Boss 2006), and biological parameters, e.g. chlorophyll a (chl) concentration (Loisel \& Morel 1998), are estimated from the particulate beam attenuation coefficient $\left(c_{\mathrm{p}}\right)$. Since heterotrophic marine bacteria (HB) and phytoplankton dominate light scattering in the open ocean (Stramski \& Kiefer 1991), and $C_{\mathrm{p}}$ is mainly determined by particulate scattering (Bricaud et al. 1988), relationships between $C_{\mathrm{p}}$ and HB could be anticipated. Detritus (non-living organic and mineral particles) is probably another important optical constituent contributing to $C_{\mathrm{p}}$ magnitude (30 to >50\%) (DuRand \& Olson 1996, Claustre et al. 1999, Stramski et al. 2001, Green et al. 2003, Oubelkheir et al. 2005, Grob et al. 2007). However, calculation of this contribution is very uncertain and results in very small $(\sim 0)$ or large (>total $C_{\mathrm{p}}$ ) estimates. Based on empirical functions between $\mathrm{HB}$ abundance (BA) and chl (Cole et al. 1988), Morel \& Ahn (1990) proposed a power type relationship be- tween scattering coefficient of $\mathrm{HB}\left(b_{\mathrm{HB}}=c_{\mathrm{HB}}-a_{\mathrm{HB}}\right.$, where $a_{\mathrm{HB}}=$ particulate absorption coefficient of $\mathrm{HB} \approx 0$, Table 1) and chl. A correlation between HB abundance and $c_{\mathrm{p}}$ as a function of depth was evident in Peruvian coastal waters (Tau correlation coefficient $=$ 0.295 to 0.646) (Spinrad et al. 1989a). Despite this established linkage between $c_{\mathrm{p}}$ and $\mathrm{HB}$, these relationships may not be universal as several studies report a lack of dependency between BA and chl (Bird \& Karl 1999, Duarte et al. 2005). Given this, the question therefore arises: To what extent can HB concentration be estimated from $c_{\mathrm{p}}$ measurements?

In general, influence of $\mathrm{HB}$ on $C_{\mathrm{p}}$ magnitude is variable $\left(0.05\right.$ to $0.5 \%$ of $C_{\mathrm{p}}$ ) (Chung et al. 1996, DuRand \& Olson 1996, Green et al. 2003, Oubelkheir et al. 2005) and is inversely related to phytoplankton biomass (e.g. oligotrophic waters: up to $50 \%$; eutrophic waters: up to $5 \%$ ) (Stramski \& Kiefer 1991, Grob et al. 2007). Based on bacterial incubations (lab cultures and mesocosms) or field samples collected in different oceanic environments, the proportion of $c_{\mathrm{p}}$ contributed per bacterial cell varies by a factor of $20\left(1 \times 10^{-14}\right.$ to $1.8 \times 10^{-13} \mathrm{~m}^{-1}$ cell $^{-1}$ ). This large variance in the scattering cross sec- 
tion per spherical bacterium $\left(\sigma_{\mathrm{HB}}\right.$, Table 1$)$ reported in the literature is partially related to methodological differences in calculating $C_{\mathrm{HB}}$. Approaches to compute $C_{\mathrm{HB}}$ differ regarding assumptions (e.g. constant versus variable parameterization) about HB cell size (Chung et al. 1998, Green et al. 2003, Oubelkheir et al. 2005) and the real part of the refractive index $\left(n_{\mathrm{HB}}\right)$ (Chung et al. 1998, Green et al. 2003), trophic status of HB during incubation experiments (Stramski \& Kiefer 1998) and theories (e.g. exact versus approximate) used to derive $\sigma_{\mathrm{HB}}$ and scattering efficiencies of $\mathrm{HB}\left(Q_{\mathrm{HB}}\right)$ (DuRand \& Olson 1996, Chung et al. 1998, Green et al. 2003, Grob et al. 2007). The wide range of $\sigma_{\mathrm{HB}}$ values between studies may also respond to natural variability between oceanic areas with distinct hydrographic and nutrient regimes. These environmental conditions are expected to affect $\sigma_{\mathrm{HB}}$ by altering bacterial cell size, shape and chemical composition (Stramski \& Kiefer 1991, 1998).

The aforementioned uncertainties on how HB affect $C_{\mathrm{p}}$ variability and magnitude in marine waters can be better constrained by standardizing the calculation of $C_{\mathrm{HB}}$ and having a more representative characterization of bacterial assemblages inhabiting the oceanic domains. With this in mind, the objective of the present study was to answer the following questions: (1) Is $C_{\mathrm{p}}$ more sensitive to optical contribution of HB in Antarctic or non-polar waters? (2) To what extent is there spatial covariation of $c_{\mathrm{p}}$, HB and chl when comparing Antarctic and non-polar surveys? (3) Which attribute of bacteria (BA, $n_{\mathrm{HB}}$, cell size or shape) dominates $C_{\mathrm{p}}$ response as a function of latitude? We hypothesized

Table 1. Definitions of abbreviations, symbols and terms used throughout the text

\begin{tabular}{|c|c|c|}
\hline Symbol & Definition & Units \\
\hline HB & Heterotrophic marine bacteria & \\
\hline pdf & Probability distribution function & Dimensionless \\
\hline ADT & Anomalous diffraction theory & \\
\hline GRA & Gaussian-Ray approximation & \\
\hline$d$ & Mean cell diameter of bacteria & $\mu \mathrm{m}$ \\
\hline BA & Bacteria abundance per unit of volume & cells $\mathrm{m}^{-3}$ \\
\hline BV & Average biovolume per cell & $\mu \mathrm{m}^{3}$ \\
\hline$\lambda$ & Light wavelength & $\mu \mathrm{m}$ \\
\hline$\alpha$ & Size parameter & Dimensionless \\
\hline$\rho$ & Phase shift & Dimensionless \\
\hline$C_{\mathrm{p}}$ & Particulate beam attenuation coefficient & $\mathrm{m}^{-1}$ \\
\hline$C_{\mathrm{HB}}$ & Particulate beam attenuation due to spherical HB & $\mathrm{m}^{-1}$ \\
\hline$\sigma_{\mathrm{HB}}$ & Scattering cross section per spherical bacterium & $\mathrm{m}^{2}$ cell $^{-1}$ \\
\hline$\sigma_{\mathrm{HB}}^{\text {cylin }}$ & Scattering cross section per cylindrical bacterium & $\mathrm{m}^{2} \operatorname{cell}^{-1}$ \\
\hline$Q_{\mathrm{HB}}$ & Scattering efficiency factor & Dimensionless \\
\hline$Q_{C}$ & Attenuation efficiency factor for heterotrophic bacteria & Dimensionless \\
\hline$S_{\mathrm{HB}}$ & Geometrical cross section of spherical HB & $\mathrm{m}^{2}$ \\
\hline$S_{\mathrm{HB}}^{\text {cylin }}$ & Geometrical cross section of cylindrical HB & $\mathrm{m}^{2}$ \\
\hline$n_{\mathrm{HB}}$ & $\begin{array}{l}\text { Real part of refractive index of } \mathrm{HB} \text { relative } \\
\text { to seawater }\end{array}$ & Dimensionless \\
\hline $\begin{array}{l}n_{W} \\
\text { PCSA }\end{array}$ & $\begin{array}{l}\text { Real part of refractive index of seawater } \\
\text { Particle cross-sectional area per } \mathrm{m}^{3}\end{array}$ & $\begin{array}{l}\text { Dimensionless } \\
\mathrm{m}^{-1}\end{array}$ \\
\hline
\end{tabular}

that contribution of $\mathrm{HB}$ to $C_{\mathrm{p}}$ magnitude and horizontal variability is larger in non-polar surveys with respect to those conducted in Antarctic waters due to the greater abundance of HB at low and mid latitudes.

\section{MATERIALS AND METHODS}

Surface measurements (average within 0 to $20 \mathrm{~m}$ depth) of $c_{\mathrm{p}}(\lambda=660 \mathrm{~nm})$, number of bacterial cells per unit of volume (BA), biovolume per cell (BV) and chl were obtained from 10 oceanographic cruises conducted during the Joint Global Ocean Flux Study (JGOFS, www.whoi.edu/) project. The surveys were representative of low $\left(5^{\circ} \mathrm{N}\right.$ to $5^{\circ} \mathrm{S}$, equatorial Pacific Ocean, EQP), mid $\left(10^{\circ} \mathrm{N}\right.$ to $22.5^{\circ} \mathrm{N}$, Arabian Sea, $\mathrm{ARAB})$, and high $\left(50.2^{\circ} \mathrm{S}\right.$ to $70.4^{\circ} \mathrm{S}$, Antarctic Polar Front, $\mathrm{APF} ; 73.5^{\circ} \mathrm{N}$ to $78.0^{\circ} \mathrm{S}$, Ross Sea, RS) latitude environments. Overall, the datasets encompassed waters with different trophic states (chl range 0.01 to $13.02 \mathrm{mg} \mathrm{m}^{-3}$ ) and ocean conditions (monsoon versus intermonsoon regime, El Niño warm versus cold phase), and sites were predominantly oceanic except in RS surveys where some locations were influenced by coastal shelf features. For each sampling station, the average of each variable was calculated along the vertical, and comparisons between $C_{\mathrm{p}}$, chl, and HB parameters were performed with data collected less than $4 \mathrm{~h}$ apart. For all cruises, the average coefficient of variation ( $\% \mathrm{CV}=100 \times \mathrm{SD} / \mathrm{mean}$ ) of $c_{\mathrm{p}}$, chl, BV and BA measurements between 0 and $20 \mathrm{~m}$ depth was $7.1,16$, 9.5 , and $12.5 \%$, respectively.

In all cases, $C_{\mathrm{p}}$ was derived from light transmission values (RS, EQP, ARAB: path length $=0.25 \mathrm{~m}$; APF: path length $=0.20 \mathrm{~m}_{\text {; }}$ accuracy $\sim 0.005 \mathrm{~m}^{-1}$, sensitivity $\left.=0.0012 \mathrm{~m}^{-1}\right)($ Spinrad et al. 1989b, Bishop 1999). Raw transmission data from SeaBird CTD files were averaged at 1 to $2 \mathrm{~dB}$ intervals and spikes were removed. Sea Tech transmissometers were calibrated by the manufacturer to have a total beam attenuation in particle-free seawater $\left(C_{W}\right)$ of $0.364 \mathrm{~m}^{-1}$. A different transmissometer was used (WetLabs) only during APF-2, but its measurements were matched with Sea Tech using an offset of $0.0151 \mathrm{~m}^{-1}$ following JGOFS protocols (http://usjgofs. whoi.edu/jg/dir/jgofs). Values of total beam attenuation $(c)$ were detrended from the decay of the transmissometer light-emitting diode (LED) during each survey. The data were also adjusted for factory and cruise air calibrations and 
corrected for changing temperature, salinity, pressure and refractive index of seawater. For each cast, $c_{\mathrm{p}}$ was calculated by subtracting $C_{W}$ and adding an offset value related to the minimum value of $C_{\mathrm{p}}$ measured between 0 and $400 \mathrm{~m}$ stations (Chung et al. 1996). This offset is obtained from the intercept of $c_{\mathrm{p}}$ as a function of POC stations (JGOFS protocols), and provides consistency between $C_{\mathrm{p}}$ profiles since systematic biases are eliminated (e.g. signal drift, incomplete cleaning of optical windows, change of sensor). For all datasets, bias to $C_{\mathrm{p}}$ due to incomplete correction by light absorption of yellow substances is expected to be minimal at a wavelength of $660 \mathrm{~nm}$ since the absorption coefficient of chromophoric dissolved compounds $\left(a_{g}\right)$ at that wavelength always represented a small fraction of $C_{\mathrm{p}}(0.05$ to $1.5 \%$; SeaBass, NASA, http://seabass.gsfc.nasa. gov). In Antarctic waters, $a_{g} / c_{\mathrm{p}}$ at $660 \mathrm{~nm}$ are commonly less than $0.3 \%$ and corresponded to the lower range of $C_{\mathrm{HB}} / C_{\mathrm{p}}$ calculated for RS and APF.

$\mathrm{BA}$ and $\mathrm{BV}$ values were estimated using digital image analysis of video microscopic images of bacterial, cellular perimeter and area (JGOFS cruises) (Baldwin \& Bankston 1988, Knap et al. 1994). Typical precision of BA and BV measurements using video images is $5 \%$ (Bjørnsen 1986). Based on microscopic sizing of fluorescent latex beads, accuracy of BV is expected to be close to $10 \%$ (Bjørnsen 1986). In general, most of the HB estimations represent the bulk community of $\mathrm{HB}$ as a whole; thus, they do not make a distinction between free-living and particle-attached assemblages. However, most of HB are expected to be freeliving bacteria, as underestimation of BA due to particle-attached bacteria is commonly less than $10 \%(\mathrm{H}$. Ducklow pers. obs.). For all cruises, chl concentrations were measured in situ using a fluorometer previously calibrated (sensivity $\sim 0.01 \mu \mathrm{g}^{-1}$ ) with discrete samples (JGOFS protocols, W. Gardner pers. comm.).

Models to estimate partial contribution of $\mathrm{HB}$ to $\boldsymbol{c}_{\mathrm{p}}$. Non-pigmented bacteria have only a minimal absorption of photons in the spectral range of 406 to $415 \mathrm{~nm}$, which is probably due to the Soret band of respiratory cytochromes (Stramski \& Kiefer 1998). Therefore, at a wavelength of $660 \mathrm{~nm}, a_{\mathrm{HB}}$ approximates $0\left(\sim 10^{-4} \mathrm{~m}^{-1}\right)$ and $C_{\mathrm{HB}}$ is approximately equal to $b_{\mathrm{HB}}$ (Morel \& Ahn 1990) (Table 1) as follows:

$$
c_{\mathrm{HB}}=b_{\mathrm{HB}}=\mathrm{BA} \times S_{\mathrm{HB}} \times Q_{\mathrm{HB}}
$$

where BA is bacterial abundance per unit of volume, $S_{\mathrm{HB}}$ is the geometric cross section $\left(\pi / 4 \times d^{2}\right.$, where $d$ is diameter of the cell in $\left.\mathrm{m}, d=2 \times[(3 / 4) \mathrm{BV} / \pi]^{1 / 3}\right), Q_{\mathrm{HB}}$ is the dimensionless scattering efficiency factor (Van de Hulst 1957), and $S_{\mathrm{HB}} \times Q_{\mathrm{HB}}$ is the scattering cross section $\left(\sigma_{\mathrm{HB}}\right)$. Note that $\mathrm{BA}, S_{\mathrm{HB}}, Q_{\mathrm{HB}}$, and $\sigma_{\mathrm{HB}}$ represent averaged values for each location and are calculated for a community of spherical HB composed of organ- isms with different refractive indices $m\left(m=n-i \times n^{\prime}\right.$, where $i^{2}=-1$ and $n$ and $n^{\prime}$ are the real and imaginary parts, respectively). The term $m$ is relative with respect to the refractive index of pure seawater $\left(n_{\mathrm{W}}\right)$, and for $\mathrm{HB}, m \cong n \cong 1$ and $n$ ' is close to 0 . Based on this simplification, the anomalous diffraction theory (ADT, Van de Hulst 1957) can be applied to estimate $Q_{\mathrm{HB}}$ of homogeneous and non-absorbing microspheres as follows:

$$
\begin{aligned}
& Q_{\mathrm{HB}}(\rho)=Q_{C}(\rho)=2-(4 / \rho) \sin \rho+\left(4 / \rho^{2}\right)(1-\cos \rho) \\
& \rho=2 \alpha\left(n_{\mathrm{HB}}-1\right) \\
& \text { and } \\
& \alpha=\left(\pi d / \lambda_{\mathrm{O}}\right) n_{\mathrm{W}}
\end{aligned}
$$

where $\alpha$ is a dimensionless size parameter, $\lambda_{\mathrm{O}}$ is the wavelength in vacuo $\left(0.66 \times 10^{-6} \mathrm{~m}\right), n_{\mathrm{W}}$ depends on sea surface temperature and salinity (Quan \& Fry 1995) and $\rho$ (phase lag) is another dimensionless parameter. Note that Eqs. (3) \& (4) are valid for a single size class of particles or particles with a very narrow range of diameters like HB. For all surveys, the real part of the refractive index of $\mathrm{HB}\left(n_{\mathrm{HB}}\right)$ was derived empirically as a function of HB diameter $(\mu \mathrm{m})$ (Stramski \& Kiefer 1990) according to the relationship:

$$
n_{\mathrm{HB}}=1+0.025 d^{-1.2} \quad\left(\mathrm{r}^{2}=0.99\right)
$$

This relationship is based on cellular water content (by vol.) between 55 and $75 \%$ and cell volume measurements obtained from 3 bacterial cultures (Simon \& Azam 1989). In general, smaller bacterial cells (high $n_{\mathrm{HB}}$ values) are more dehydrated and have a larger proportion of volume occupied by proteins than bigger bacterial cells (low $n_{\mathrm{HB}}$ values). Based on bacterial intracellular carbon content $\left(\mathrm{C}_{\mathrm{CELL}}\right), n_{\mathrm{HB}}$ can also be inversely related to water content per cell ( $V_{\mathrm{w}}$, Morel \& Ahn 1990).

Given that $\mathrm{C}_{\mathrm{CELL}}$ is generally more variable ( $>5$-fold) than $\mathrm{C} / \mathrm{N}(\sim 1.5$-fold $), n_{\mathrm{HB}}$ can be modeled as a linear function of $\mathrm{C}_{\mathrm{CELL}}\left(n_{\mathrm{HB}}=1+0.233 \times 10^{-3} \mathrm{C}_{\mathrm{CELL}}\right.$, Morel \& Ahn 1990). Likewise, and assuming a constant density of dry organic matter $\left(\rho_{\mathrm{O}}\right), \mathrm{C}_{\mathrm{CELL}}$ is inversely related to $V_{\mathrm{w}}\left[\mathrm{C}_{\mathrm{CELL}}=\left(1-V_{\mathrm{w}}\right) \rho_{\mathrm{O}}\right]$ (Morel \& Ahn 1990). Since $V_{\mathrm{w}}$ is directly related to BV and $d$ (assuming a spherical shape) $\left(V_{\mathrm{w}}=1.0515 d^{0.6104}, \mathrm{r}^{2}=0.92, \mathrm{n}=7\right.$, Simon \& Azam 1989), it is deduced that smaller bacterial cells will be, on average, more efficient at scattering light (high $n_{\mathrm{HB}}$, low $V_{\mathrm{w}}$ ) due to a higher $\mathrm{C}_{\mathrm{CELL}}$. Characteristic relative errors for lab determinations of $n_{\mathrm{W}}$ and $n_{\mathrm{HB}}$ are 0.02 (Quan \& Fry 1995) and 0.1\% (Jonasz et al. 1997), respectively.

In general, calculation of optical parameters of $\mathrm{HB}$ derived from the above equations assumes a community of unattached and free-floating HB. Field studies across different oceanic regions support this view (Wiebe \& Pomeroy 1972, Sieburth et al. 1974). Eventually, a violation of this assumption may occur during 
senescent phytoplankton blooms or events characterized by waters with an abundant concentration of detritus and formation of aggregates (Abell \& Bowman 2005). Assuming a minimum breakage of micro-aggregates ( 5 to $500 \mu \mathrm{m})$ during counting, a larger fraction of aggregate-attached $\mathrm{HB}$ may decrease $C_{\mathrm{HB}} / C_{\mathrm{p}}$ due to underestimation of particle-attached BA (i.e. freeliving $\mathrm{HB}$ are easier to count). On the contrary, if breakage of micro-aggregates is major, a greater proportion of bacteria bound to aggregates would be counted, and $C_{\mathrm{HB}} / c_{\mathrm{p}}$ would increase due to a greater mean cell size of particle-attached HB compared to free-living HB (Grossart et al. 2003).

Total error in $S_{\mathrm{HB}}, Q_{\mathrm{HB}}, \sigma_{\mathrm{HB}}, n_{\mathrm{HB}}$ and $c_{\mathrm{HB}}$ calculations was determined based on error propagation theory. To obtain mean relative bias of each HB optical parameter, random absolute bias was generated for BA and $d$ (Monte Carlo simulations, Matlab 7.5). Uncertainty on $\mathrm{BA}(d \mathrm{BA})$ was allowed to change, i.e. $(\mathrm{BA}-0.05 \mathrm{BA}) \leq$ $d \mathrm{BA} \leq(\mathrm{BA}+0.05 \mathrm{BA})$. Bias on $d$ depends on bacterial cell size and was obtained from the absolute difference between specified and measured BV (Bjørnsen 1986). To compute $n_{\mathrm{HB}}, 2$ errors were added: one randomly derived from $d$ and the other inherited from the relationship of $n_{\mathrm{HB}}$ as a function of $d\left(\sim 0.2238 \%\right.$ of $\left.n_{\mathrm{HB}}\right)$ (Stramski \& Kiefer 1990).

Scattering cross sections of homogeneous (noncoated) and non-spherical (cylindrical) HB were calculated based on the Gaussian Ray approximation (GRA) (Katz et al. 2003):

$$
\sigma_{\mathrm{HB}}{ }^{\text {cylin }}=32 \times\left(n_{W} \times 2 \pi^{3} \times\left|n_{\mathrm{HB}}-1\right| \times 2 r^{3} l\right) /\left(3 \lambda_{\mathrm{O}}{ }^{2}\right)
$$

For randomly oriented bacteria, $r$ and $l$ are the radius and length of the cylinder, respectively. The length of the cylinder was equivalent to the diameter of HB considering a spherical shape $(l=d)$ while the cylinder radius was calculated as $1 / 2.5$ and assuming a cylinder diameter of 0.81 (Ulloa et al. 1992). Likewise, the mean projected area or geometrical cross section of bacterial rods was computed according to Cauchy's theorem: $S_{\mathrm{HB}}{ }^{\text {cylin }}=\pi r(r+1) / 2$ (Brown et al. 2005). The GRA is a statistical interpretation of ADT that assumes soft particles ( $n$ is close to 1 ). The influence of the bacterial cell wall on $C_{\mathrm{HB}}$ calculations is assumed to be minor since most of the bacteria inhabiting marine waters are gram negative with relatively thin cell walls ( 5 to $10 \mathrm{~nm})$ (Agogué et al. 2005); thus, scattering properties will depend more on size, shape and refraction index of cells (Katz et al. 2003).

Statistical analysis. Linear regression (type II model) was used to quantify the influence of $\mathrm{HB}$ on $C_{\mathrm{p}}$ variability at high, low and mid latitude surveys. Due to the low degrees of freedom of individual surveys, spatial dependency of $c_{\mathrm{p}}$ on $c_{\mathrm{HB}}$ was examined by merging multiple datasets. Multiple regression analysis with forward elimination of continuous predictors (Statistica software v7.1) was applied a posteriori to rank the relative contribution of $n_{\mathrm{HB}}$, BV and BA to horizontal variability of $c_{\mathrm{HB}}$. Since $n_{\mathrm{HB}}$ and BV are interdependent, relationships between $\mathrm{BV}$ and $C_{\mathrm{HB}}$ are also implicitly influenced by the chemical composition of bacteria. Latitudinal differences in optical and HB parameters were examined with Student's $t$-test $\left(\mathrm{H}_{0}: \mu_{\text {Antarctic }}=\right.$ $\mu_{\text {non-polar }}$ ) following analysis of homogeneity of variances with an F-test $\left(\mathrm{H}_{0}: s^{2}\right.$ Antarctic $=s^{2}$ non-polar $)$. Multivariate models were constructed using measurements without distinction by time of day; thus, $C_{\mathrm{HB}}$ estimations represented ecological conditions averaged for day and night. Unlike the high latitude datasets, the non-polar group included surveys performed during periods of strong (monsoon season and El Niño cold phase) and weak (El Niño warm phase) or absent (intermonsoon) upwelling conditions. The physical forces triggering intermonsoons (wind reversal) and El Niño warm phase (Kelvin wave propagation) events are different, but in both cases produce a general nutrient depletion in surface layers. Unlike the Arabian Sea, upwelling continues during the warm phase of El Niño but at depths above the nutricline. These events have distinct levels of primary production (Ducklow et al. 1995, 2001a); thus, they are expected to affect the contribution of $\mathrm{HB}$ to $c_{\mathrm{p}}$ differently.

\section{RESULTS}

\section{Contribution of $\mathrm{HB}$ to $c_{\mathrm{p}}$ magnitude}

As previous studies have suggested, HB was not the major optical component determining $C_{\mathrm{p}}$ magnitude for any of the regions studied, with a maximum contribution of $19 \%$ in the Ross Sea (Table 2). This is considerably lower than theoretical maximum predictions of up to $50 \%$ (Stramski \& Kiefer 1991). Overall, most of the $C_{\mathrm{HB}} / C_{\mathrm{p}}$ values were below $10 \%$ (polar, $85.3 \%$ of samples, $\mathrm{n}=109$; non-polar, $77.2 \%$ of samples, $\mathrm{n}=54$ ). Average HB contributions to $c_{\mathrm{p}}$ were $8.2 \pm 0.7 \%$ (mean \pm $2 \mathrm{SD}$ ) in non-polar waters and only $3.7 \pm 0.7 \%$ in Antarctic waters (Student's $t$-statistic $=1.98, \mathrm{p}<0.01$ ). Survey-to-survey comparisons also indicated that bacteria of Antarctic marine environments may have $C_{\mathrm{HB}} / C_{\mathrm{p}}$ values comparable to low and mid latitude environments during some periods of the year (e.g. RS-3 versus EQP-1). Further analysis relating particle crosssectional area per unit of volume (PCSA) with $C_{\mathrm{p}}$ and $C_{\mathrm{p}} /$ PCSA confirmed that contribution of $\mathrm{HB}$ to $C_{\mathrm{p}}$ in the Southern Ocean is small compared with other particulate components (Appendix 1, Fig. A1). In fact, phytoplankton cells explained a larger variability of $C_{\mathrm{p}}$ in Antarctic waters $\left[c_{\mathrm{p}}=0.1903( \pm 0.007,1 \mathrm{SE}) \times \mathrm{chl}+\right.$ 
$\left.0.1518( \pm 0.0184), \mathrm{r}^{2}=0.89, \mathrm{n}=102\right]$ compared with low and mid latitude surveys $\left[c_{\mathrm{p}}=0.0614( \pm 0.0106) \times \mathrm{chl}+\right.$ $\left.0.0798( \pm 0.0106), r^{2}=0.42, n=48\right]$.

In general, for non-polar surveys, intra-cruise (up to 3 -fold) and inter-cruise (up to 2-fold) maximum variability of $C_{\mathrm{HB}} / c_{\mathrm{p}}$ was comparable (Table 2). Interestingly, maximum values of average $C_{\mathrm{HB}} / C_{\mathrm{p}}$ per survey (15.1 to $19 \%$ ) coincided with the lowest average values of total particulate beam attenuation (e.g. $C_{\mathrm{p}}<0.1 \mathrm{~m}^{-1}$ in RS-3 and EQP-1). This pattern suggests that $C_{\mathrm{HB}}$ is relatively constant in magnitude, and that variability in its percentage contribution is more related to fluctuations in other optical components. Although the data analyzed seem to indicate that HB comprises a larger proportion of $c_{\mathrm{p}}$ during periods with an oligotrophic regime and characterized by reduced upwelling intensity (intermonsoon season, ARAB-1, El Niño warm phase EQP-1) (Table 2), the existence of this pattern requires further verification since the computation error of $C_{\mathrm{HB}} / C_{\mathrm{p}}$ in these waters is approximately 10 -fold greater than the observed differences on $C_{\mathrm{HB}} / C_{\mathrm{p}}$ due to distinct upwelling conditions or trophic status. For individual cruises, a greater contribution of $\mathrm{HB}$ to $C_{\mathrm{p}}$ magnitude was either determined by changes on $\mathrm{HB}$ counts (APF), BV (ARAB, EQP) or $n_{\mathrm{HB}}(\mathrm{RS})$ (Tables 2 \& $3)$. In general, the low and mid latitude surveys were characterized by a greater average of $n_{\mathrm{HB}}(1.073 \pm$ 0.005 , mean $\pm \mathrm{SE})$, BA $\left(9.68 \pm 0.94 \times 10^{11}\right.$ cells m $\left.\mathrm{m}^{-3}\right)$ and smaller bacterial diameter $(d=0.416 \pm 0.013 \mu \mathrm{m})$ compared to $n_{\mathrm{HB}}(1.060 \pm 0.005)$, BA $\left(6.12 \pm 0.94 \times 10^{11}\right.$ cells $\left.\mathrm{m}^{-3}\right)$ and $d(0.491 \pm 0.014 \mu \mathrm{m})$ of Antarctic surveys (Student's $t$-statistic $=1.97, \mathrm{p}<0.01 ;$ Table $3 ;$ Appendix 2, Fig. A2). In general, and as inferred from BV range, variability of BV in surface waters was more uniform in

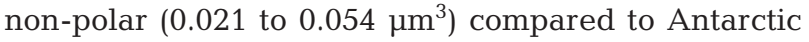
$\left(0.024\right.$ to $\left.0.160 \mathrm{~mm}^{3}\right)$ surveys $(F$-statistic $=2.94, \mathrm{p}<0.01$; Appendix 2, Fig. A2). The influence of bacterial cell shape did not considerably affect the contribution of bacteria to the magnitude of $c_{\mathrm{p}}$. In general, a microbial population entirely composed of bacterial rods had

Table 2. Contribution of heterotrophic bacteria to $C_{\mathrm{p}}$ magnitude in surface waters $(0$ to $20 \mathrm{~m})$ of different marine regions: For each cruise, the average and range (minimum-maximum) of surface values ( 0 to $20 \mathrm{~m}$ depth) are indicated in the first and second row, respectively; $C_{\mathrm{p}}$ values were measured at $\lambda=660 \mathrm{~nm}\left(\mathrm{~m}^{-1}\right)$. chl: chlorophyll a concentration $\left(\mathrm{mg} \mathrm{m}^{-3}\right)$; $\mathrm{n}$ : number of observations; $Q_{\mathrm{HB}}$ : dimensionless scattering efficiency factor $\left(10^{-2}\right) ; \sigma_{\mathrm{HB}}$ : scattering cross section of $\mathrm{HB}\left(\mathrm{m}^{2} \mathrm{cell}^{-1}\right) \times 10^{-14}, c_{\mathrm{HB}} / C_{\mathrm{p}}(\%)$ : percentage of $c_{\mathrm{p}}$ due to HB. Assuming a spherical shape of bacterial cells, relative biases of $S_{\mathrm{HB}}, Q_{\mathrm{HB}}, \sigma_{\mathrm{HB}}$ and $c_{\mathrm{HB}}$ in percentage were \pm 0.9 , $\pm 35.7, \pm 36.8$ and $\pm 36.1 \%$ (Antarctic surveys) and $\pm 0.8, \pm 31.3, \pm 39.4$ and $\pm 31.7 \%$ (non-polar surveys), respectively. In the Arabian Sea, June to September and September to March coincided with monsoon (wet months, summer) and inter-monsoon (dry months, winter) seasons, respectively. In the equatorial Pacific, August and September 1992 corresponded with the El Niño cold phase

\begin{tabular}{|c|c|c|c|c|c|c|}
\hline $\begin{array}{l}\text { Cruise no. } \\
\text { (Dates) }\end{array}$ & $Q_{\mathrm{HB}}$ & $\sigma_{\mathrm{HB}}$ & $C_{\mathrm{HB}} / C_{\mathrm{p}}(\%)$ & $C_{\mathrm{p}}$ & chl & $\mathrm{n}$ \\
\hline \multicolumn{7}{|l|}{ Ross Sea } \\
\hline $\begin{array}{l}\text { RS-1 } \\
\text { Oct-Nov } 1996\end{array}$ & $\begin{array}{c}7.11 \\
(6.57-7.41)\end{array}$ & $\begin{array}{c}1.04 \\
(0.90-1.20)\end{array}$ & $\begin{array}{c}2.1 \\
(0.7-5.2)\end{array}$ & $\begin{array}{c}0.067 \\
(0.016-0.200)\end{array}$ & $\begin{array}{c}0.13 \\
(0.01-0.43)\end{array}$ & 18 \\
\hline $\begin{array}{l}\text { RS-2 } \\
\text { Jan-Feb } 1997\end{array}$ & $\begin{array}{c}6.58 \\
(5.77-7.03)\end{array}$ & $\begin{array}{c}1.41 \\
(1.08-1.65)\end{array}$ & $\begin{array}{c}3.1 \\
(0.52-9.8)\end{array}$ & $\begin{array}{c}0.837 \\
(0.301-1.720)\end{array}$ & $\begin{array}{c}3.55 \\
(0.10-9.66)\end{array}$ & 20 \\
\hline $\begin{array}{l}\text { RS-3 } \\
\text { Apr-Mar } 1997\end{array}$ & $\begin{array}{c}7.05 \\
(6.58-7.50)\end{array}$ & $\begin{array}{c}1.07 \\
(0.98-1.26)\end{array}$ & $\begin{array}{c}11.4 \\
(6.7-19.0)\end{array}$ & $\begin{array}{c}0.031 \\
(0.022-0.064)\end{array}$ & $\begin{array}{c}0.03 \\
(0.01-0.05)\end{array}$ & 12 \\
\hline $\begin{array}{l}\text { RS-4 } \\
\text { Nov-Dec } 1997\end{array}$ & $\begin{array}{c}6.43 \\
(5.53-7.23)\end{array}$ & $\begin{array}{c}1.54 \\
(0.97-2.07)\end{array}$ & $\begin{array}{c}1.9 \\
(0.3-4.1)\end{array}$ & $\begin{array}{c}0.551 \\
(0.076-2.442)\end{array}$ & $\begin{array}{c}1.92 \\
(0.08-13.02)\end{array}$ & 34 \\
\hline \multicolumn{7}{|l|}{ Antarctic Polar Front } \\
\hline $\begin{array}{l}\text { APF-1 } \\
\text { Dec 1997-Jan } 1998\end{array}$ & $\begin{array}{c}6.78 \\
(6.02-7.78)\end{array}$ & $\begin{array}{c}1.24 \\
(0.83-1.58)\end{array}$ & $\begin{array}{c}2.4 \\
(0.3-7.9)\end{array}$ & $\begin{array}{c}0.394 \\
(0.115-0.730)\end{array}$ & $\begin{array}{c}0.08 \\
(0.02-0.18)\end{array}$ & 11 \\
\hline $\begin{array}{l}\text { APF-2 } \\
\text { Feb-Mar } 1998\end{array}$ & $\begin{array}{c}7.07 \\
(6.35-7.66)\end{array}$ & $\begin{array}{c}1.07 \\
(0.76-1.29)\end{array}$ & $\begin{array}{c}6.7 \\
(1.4-1.3)\end{array}$ & $\begin{array}{c}0.140 \\
(0.06-0.335)\end{array}$ & $\begin{array}{c}0.05 \\
(0.02-0.06)\end{array}$ & 16 \\
\hline \multicolumn{7}{|l|}{ Arabian Sea } \\
\hline $\begin{array}{l}\text { ARAB-1 } \\
\text { Mar-Apr } 1995\end{array}$ & $\begin{array}{c}7.52 \\
(6.82-7.93)\end{array}$ & $\begin{array}{c}0.85 \\
(0.72-1.14)\end{array}$ & $\begin{array}{c}6.7 \\
(2.9-8.7)\end{array}$ & $\begin{array}{c}0.166 \\
(0.085-0.260)\end{array}$ & $\begin{array}{c}0.53 \\
(0.03-1.60)\end{array}$ & 15 \\
\hline $\begin{array}{l}\text { ARAB-2 } \\
\text { Jul-Aug } 1992\end{array}$ & $\begin{array}{c}7.59 \\
(7.16-7.82)\end{array}$ & $\begin{array}{c}0.83 \\
(0.75-0.92)\end{array}$ & $\begin{array}{c}6.1 \\
(2.8-7.6)\end{array}$ & $\begin{array}{c}0.177 \\
(0.102-0.285)\end{array}$ & $\begin{array}{c}1.85 \\
(0.63-3.48)\end{array}$ & 7 \\
\hline \multicolumn{7}{|c|}{ Equatorial Pacific Ocean } \\
\hline $\begin{array}{l}\text { EQP-1 } \\
\quad \text { Mar-Apr } 1992\end{array}$ & $\begin{array}{c}6.93 \\
(6.41-7.33)\end{array}$ & $\begin{array}{c}1.13 \\
(1.00-1.24)\end{array}$ & $\begin{array}{c}10.9 \\
(7.3-15.1)\end{array}$ & $\begin{array}{c}0.074 \\
(0.052-0.103)\end{array}$ & $\begin{array}{c}0.52 \\
(0.43-0.65)\end{array}$ & 17 \\
\hline $\begin{array}{l}\text { EQP-2 } \\
\text { Sep-Oct } 1992\end{array}$ & $\begin{array}{c}7.10 \\
(6.71-7.61)\end{array}$ & $\begin{array}{c}1.01 \\
(0.92-1.12)\end{array}$ & $\begin{array}{c}7.8 \\
(4.3-12.6)\end{array}$ & $\begin{array}{c}0.117 \\
(0.085-0.168)\end{array}$ & $\begin{array}{c}0.70 \\
(0.39-0.89)\end{array}$ & 20 \\
\hline
\end{tabular}


Table 3. Summary of heterotrophic bacteria (HB) parameters used to estimate $C_{\mathrm{HB}} \cdot n_{\mathrm{HB}}$ : real part of relative refractive index of $\mathrm{HB}$; BA: number of bacteria per unit of volume (cells $\left.\mathrm{m}^{-3}\right) \times 10^{11}$; BV: average biovolume per cell $\left(\mu \mathrm{m}^{3}\right) \times 10^{-2}$. Values are means (min-max) for $n_{\mathrm{HB}}$ and means $(+1 \mathrm{SE})$ for BA and BV. Relative biases in percentage for $n_{\mathrm{HB}}$, BA and BV were $\pm 0.39, \pm 5$ and \pm 10 , respectively. Cruise details are given in Table 2

\begin{tabular}{|lccc|}
\hline Cruise & $n_{\mathrm{HB}}$ & BA & BV \\
\hline RS-1 & $1.069(1.061-1.074)$ & $0.92(0.04)$ & $4.24(0.12)$ \\
RS-2 & $1.055(1.047-1.064)$ & $16.1(2.10)$ & $7.53(0.26)$ \\
RS-3 & $1.067(1.060-1.071)$ & $2.92(0.16)$ & $4.47(0.15)$ \\
RS-4 & $1.052(1.039-1.069)$ & $4.17(0.64)$ & $9.04(0.47)$ \\
APF-1 & $1.061(1.048-1.084)$ & $5.20(0.84)$ & $6.14(0.67)$ \\
APF-2 & $1.068(1.059-1.087)$ & $6.31(0.37)$ & $4.47(0.23)$ \\
ARAB-1 & $1.081(1.066-1.092)$ & $12.9(1.56)$ & $2.89(0.18)$ \\
ARAB-2 & $1.082(1.079-1.085)$ & $14.1(0.91)$ & $2.72(0.08)$ \\
EQP-1 & $1.064(1.060-1.070)$ & $6.89(0.22)$ & $4.97(0.01)$ \\
EQP-2 & $1.070(1.066-1.075)$ & $8.55(0.64)$ & $4.05(0.01)$ \\
\hline
\end{tabular}

Table 4. Linear regression models for estimating covariability between $C_{\mathrm{HB}}$ and $c_{\mathrm{p}}$. Polar comprises RS and APF surveys, and non-polar comprises ARAB and EQP surveys. n: number of data, $\mathrm{r}^{2}$ : coefficient of determination. $M$ and $I$ are slope and intercept of the model: $c_{\mathrm{p}}=M C_{\mathrm{HB}}+I$, respectively. For each regression parameter, statistical significance is indicated at $95 \%\left({ }^{*}\right)$ and $99 \%\left({ }^{* *}\right)$ of probability level

\begin{tabular}{|lcc|}
\hline & Polar & Non-polar \\
\hline $\mathrm{n}$ & 102 & 57 \\
$\mathrm{r}^{2}$ & $0.36^{* *}$ & $0.36^{* *}$ \\
$M$ & $30.20^{* *}$ & $10.94^{* *}$ \\
$I$ & $0.148^{*}$ & 0.022 \\
\hline
\end{tabular}

$22.5,37.2,3$ and $3 \%$ higher $Q_{\mathrm{HB}}, \sigma_{\mathrm{HB}}, C_{\mathrm{HB}}$ and $C_{\mathrm{HB}} / C_{\mathrm{p}}$ respectively, compared to a typical microbial population dominated by coccoid morphotypes.

\section{Contribution of $\mathrm{HB}$ to horizontal variability of $\boldsymbol{c}_{\mathrm{p}}$}

In general, optical light attenuation due to HB was not the main scattering source affecting $C_{\mathrm{p}}$ spatial variability in surface waters of different tropical, subtropical and Antarctic oceanic domains (Table 4 ). $C_{\mathrm{HB}}$ accounts for approximately $35 \%$ of observed variability in $c_{\mathrm{p}}$ for both Antarctic and non-polar regions. The regression slopes confirm that $C_{\mathrm{HB}}$ makes a greater contribution to $C_{\mathrm{p}}$ magnitude in non-polar waters than in Antarctic waters. However, the intercept of the $c_{\mathrm{p}}-c_{\mathrm{HB}}$ regression curve for the Antarctic group was significantly different from zero ( $p<0.05)$. As deduced from the magnitude of standardized multiple regression coefficients $(\beta)$, BA was the primary factor dictating horizontal variability of $C_{\mathrm{HB}}$ in Antarctic $\left(\beta_{\mathrm{BA}}=0.946, \beta_{\mathrm{BV}}=0.146\right)$ and non-polar $\left(\beta_{\mathrm{BA}}=\right.$ $\left.1.127, \beta_{\mathrm{BV}}=0.355\right)$ surveys $(\mathrm{p}<0.01)$.

\section{DISCUSSION}

The main focus of the present study was to calculate $C_{\mathrm{HB}}$ in oceanic regions not investigated before (Southern and Indian oceans) and to evaluate, by comparison with published data, the importance of HB contribution to $C_{\mathrm{p}}$ magnitude and variability in marine waters. This knowledge is necessary to better understand marine ecosystem functions by building more realistic biogeochemical models coupled to optical variables related to $\mathrm{HB}$ ecological processes (respiration and synthesis of POC, regulation of the 'biological pump') (Fujii et al. 2007, Claustre et al. 2008). Since $C_{\mathrm{p}}$ is not affected by changes in sunlight geometry (inherent optical property) and is secondarily influenced by the chemical composition of particulates, $c_{p}$ can be used as a specific proxy of particle concentration per unit of volume in surface marine waters. Given this, changes in bacterial abundance are expected to be reflected in $C_{\mathrm{p}}$ measurements. However, based on transmissometry, can the HB signal be discriminated from other particulate optical targets co-dominating the total beam attenuation coefficient?

Interpretation of our results is organized into 3 sections describing the variation of $C_{\mathrm{HB}} / C_{\mathrm{p}}$ due to (1) methodological differences, (2) latitudinal and seasonal variation of $C_{\mathrm{HB}} / C_{\mathrm{p}}$ magnitude and (3) $C_{\mathrm{HB}}-C_{\mathrm{p}}$ relationships in surface marine waters during Antarctic and non-polar surveys.

\section{Assumptions behind $\boldsymbol{c}_{\mathrm{HB}}$ calculations}

Analysis of uncertainties associated with $C_{\mathrm{p}}$ estimates is fundamental to evaluate the differences in marine biogeographic zones in terms of HB contribution to $c_{\mathrm{p}}$ and to provide mathematical constraints to the contribution of other $c_{\mathrm{p}}$ components (e.g. detritus) with even larger uncertainties than $C_{\mathrm{HB}}$ (Claustre et al. 1999, Grob et al. 2007). Assumptions regarding bacterial cell shape (spherical versus cylindrical) are not expected to modify the observed trends in $C_{\mathrm{HB}} / C_{\mathrm{p}}$ between Antarctic and non-polar oceanic domains. Indeed, we calculated that less than $5 \%$ change in $C_{\mathrm{HB}} / C_{\mathrm{p}}$ was due to variations in bacterial cell shape. Clavano et al. (2007) suggested that the influence of particle shape on attenuation or scattering properties is minor when particles have a mean cell size comparable with the transmissometer wavelength. Our estimations of $C_{\mathrm{HB}}$ values included a variable bacterial cell size and refractive index (real part). Among the cited references, this $d-n_{\mathrm{HB}}$ parameterization is uncommon since additional optical measurements are usually required (e.g. spectrophotometric absorption cross section) (Green et al. 2003). Most of the published studies 
report $\sigma_{\mathrm{HB}}$ values based on constant $d$ and $n_{\mathrm{HB}}$ values (Chung et al. 1998, Claustre et al. 1999, Oubelkheir et al. 2005, Grob et al. 2007). Our observed range of $d$ values $(0.34$ and $0.67 \mu \mathrm{m})$ is generally lower than the mean bacterial diameter $(0.55 \mu \mathrm{m})$ commonly chosen by other authors for calculations based on field measurements (Claustre et al. 1999) or theoretical models (Stramski \& Kiefer 1990, Oubelkheir et al. 2005). Therefore, with the only exception being results obtained from the New England continental shelf (Green et al. 2003), we suggest that HB geometrical cross sections have been overestimated in most $C_{\mathrm{HB}} / C_{\mathrm{p}}$ calculations reported in the literature $\left(\Delta C_{\mathrm{HB}} / c_{\mathrm{p}}\right.$ up to $\sim 1.5$-fold). Considering a total estimation error of $\sim 0.4 \%$, an uncertainty comparable with that suggested by Aas (1996), our estimated $n_{\mathrm{HB}}$ values (1.039 and $1.092)$ were within the range $(1.077$ to $>1.10)$ reported for shelf waters influenced by sediments (Green et al. 2003), and for bacterial lab cultures with samples collected in the California Coastal Current (1.042 to 1.068) (Stramski \& Kiefer 1990) and Bermuda Sea (1.037 to 1.038) (Jonasz et al. 1997). Note that the methodological procedure to derive $n_{\mathrm{HB}}$ differed between Green et al. (2003) (flow cytometry and Mie theory), Stramski \& Kiefer (1990) (Mie theory) and Jonasz et al. (1997) (immersion refractometry and ADA, $10 \%$ accuracy). Considering the sum of uncertainties due to $n_{\mathrm{HB}}, \mathrm{BA}$, and $d$, our calculations of $c_{\mathrm{HB}}$ $\left(C_{\mathrm{HB}} / C_{\mathrm{p}}\right)$ had a relative error of $\pm 36.1 \%( \pm 36.6 \%)$ and $\pm 31.7 \%( \pm 37.7 \%)$ for samples collected in Antarctic and non-polar waters, respectively.

\section{Contribution of $\mathrm{HB}$ to $c_{\mathrm{p}}$ magnitude}

For the first time and based on 6 Antarctic and 4 nonpolar oceanographic surveys, we present evidence that HB contribution to $c_{\mathrm{p}}$ is smaller at high latitudes ( $>2$ fold) than at low and mid latitudes. In fact, analysis of the regression intercept for $c_{p}-$ PCSA curves and probabilistic distribution of $c_{\mathrm{p}} / \mathrm{PCSA}$ confirmed the greater importance of additional optical components driving $C_{\mathrm{p}}$ in Antarctic samples compared with tropical and sub-tropical waters (Appendix 1, Fig. A1).

In general, the number of bacterial cells per unit of volume was a major factor, compared with bacterial cell size spectrum, shape or chemical composition, in explaining observed $C_{\mathrm{HB}} / C_{\mathrm{p}}$ differences. These results agree with the fact that numerical abundance of microorganisms $(d$, range 0.2 to $100 \mu \mathrm{m})$ is more sensitive $\left(\mathrm{BA} \propto d^{-4}\right.$ ) to $d$ modifications than the geometric section of the same microorganisms $\left(S_{\mathrm{HB}} \propto d^{2}\right.$ ) (Kiefer 1984). On average, bacterial size and $n_{\mathrm{HB}}$ were also different between Antarctic and non-polar surveys, but we suggest that this variation was caused by the anomalous bacterial dynamics of the Ross Sea. The Ross Sea seems to exhibit a large bacterial bloom (BV changes $\sim 4$-fold) not seen elsewhere in Antarctic waters (Ducklow et al. 2001b). Our $C_{\mathrm{HB}} / C_{\mathrm{p}}$ estimations for the sampling locations were generally below $10 \%$ and were not necessarily affected by trophic status (chl levels). In the Pacific Ocean (Grob et al. 2007), $C_{\mathrm{HB}} / c_{\mathrm{p}}$ values of surface tropical and subtropical waters (8.4 to $34.6^{\circ} \mathrm{S}$ ) were never above $15 \%$ (6.3 to $13 \%$ range), and maximum values were observed at lower latitudes. Likewise, Grob et al. (2007) did not find a clear relationship between the spatial gradients of vertically integrated ( 0 to $50 \mathrm{~m}$ ) $C_{\mathrm{HB}} / C_{\mathrm{p}}$ and $\mathrm{chl}$ values. Based on average values per survey, $C_{\mathrm{HB}} / C_{\mathrm{p}}$ was consistently lower during ARAB-2 and EQP-2 compared with ARAB-1 and EQP-1, respectively (Table 2). This effect was probably caused by a greater proportion of particulate beam attenuation due to phytoplankton with respect to $\mathrm{HB}$ during periods of surface nutrient enrichment (El Niño cold phase and summer monsoons) (Ducklow et al. 1995, 2001a).

\section{Contribution of HB to horizontal variability of $c_{\mathrm{p}}$}

Based on datasets analyzed, HB was not the main optical component explaining surface horizontal variability of $c_{\mathrm{p}}(\sim 35 \%)$ measured at $660 \mathrm{~nm}$ wave length. In the eastern South Pacific Ocean, spatial variability of $C_{\mathrm{p}}$ (at $660 \mathrm{~nm}$ ) is primarily defined by pigmented particles (Prochlorococcus, Synechococcus and eukaryotes), especially in areas with higher trophic status (Grob et al. 2007). Although HB only represented a minor fraction of $c_{\mathrm{p}}$ magnitude, the influence of bacteria on spatial variability of $c_{\mathrm{p}}$ was more important. This can be attributed to the covariation between $c_{\mathrm{p}}$, HB and other optical components such as phytoplankton (Li et al. 2004) and detritus (Abell \& Bowman 2005).

\section{CONCLUSION}

The magnitude and spatial variability of $C_{\mathrm{p}}$ were weakly modulated by $\mathrm{HB}$ in surface oceanic waters encompassing a broad latitudinal range. In all samples studied, the contribution of HB to $c_{\mathrm{p}}$ was never dominant, and $c_{\mathrm{p}}$ response to various HB concentrations was partially indirect and probably overestimated due to the existence of other optical particulate components (e.g. phytoplankton), which correlated with $c_{\mathrm{p}}$ and $\mathrm{HB}$ abundance. This may restrict the use of beam transmissometers for estimating HB biomassdependent parameters over relatively small spatial scales $(0.1$ to $100 \mathrm{~km})$. However, we suggest that averaged $C_{\mathrm{HB}} / C_{\mathrm{p}}$ values weighted over large marine 
domains (>1000 km) may be a useful ecological index for discriminating biogeographic regions with different particle dynamics.

Acknowledgements. We appreciate the suggestions from E. Boss and 2 anonymous reviewers that helped to improve the ideas developed in the present work. This study was part of the Palmer-LTER (Long-Term Ecological Research) on the western shelf of the Antarctic Peninsula, funded by NSF grant OPP-02-17282.

\section{LITERATURE CITED}

Aas E (1996) Refractive index of phytoplankton derived from its metabolite composition. J Plankton Res 18:2223-2249

Abell GCJ, Bowman JP (2005) Colonization and community dynamics of class Flavobacteria on diatom detritus in experimental mesocosms based on Southern Ocean seawater. FEMS Microbiol Ecol 53:379-391

Agogué H, Casamayor EO, Bourrain M, Obernosterer I, Joux F, Herndl G, Lebaron P (2005) A survey on bacteria inhabiting the sea surface microlayer of coastal ecosystems. FEMS Microbiol Ecol 54:269-280

Baldwin WW, Bankston PW (1988) Measurement of live bacteria by Nomarski interference microscopy and stereologic methods as tested with macroscopic rod-shaped models. Appl Environ Microbiol 54:105-109

Behrenfeld MJ, Boss E (2006) Beam attenuation and chlorophyll concentration as alternative optical indices of phytoplankton biomass. J Mar Res 64:431-451

Bird DF, Karl DM (1999) Uncoupling of bacteria and phytoplankton during the austral spring bloom in Gerlache Strait, Antarctica Peninsula. Aquat Microb Ecol 19:13-27

Bishop JKB (1999) Transmissometer measurement of POC. Deep-Sea Res I 46:353-369

Bjørnsen PK (1986) Automatic determination of bacterioplankton biomass by image analysis. Appl Environ Microbiol 51:1199-1204

Bricaud L, Beldhomme AL, Morel A (1988) Optical properties of diverse phytoplankton species: experimental results and theoretical interpretation. J Plankton Res 10:851-873

Brown DJ, Vickers GT, Collier AP, Reynolds GK (2005) Measurement of the size and orientation of convex bodies. Chem Eng Sci 60:289-292

Chung SP, Gardner WD, Richardson MJ, Walsh ID, Landry M (1996) Beam attenuation and micro-organisms: spatial and temporal variations in small particles along $140^{\circ} \mathrm{W}$ during the 1992 JGOFS EqPac transects. Deep-Sea Res II 43: 1205-1226

Chung SP, Gardner WD, Landry MR, Richardson MJ, Walsh I (1998) Beam attenuation by microorganisms and detrital particles in the equatorial Pacific. J Geophys Res 103(C6): 12669-12681

Claustre H, Morel A, Babin M, Caillau C and others (1999) Variability in particle attenuation and chlorophyll fluorescence in the tropical Pacific: scales, patterns, and biogeochemical implications. J Geophys Res 104(C2):3401-3422

Claustre H, Huot Y, Obernosterer I, Gentili B, Tailliez D, Lewis M (2008) Gross community production and metabolic balance in the south Pacific Gyre, using a non intrusive bio-optical method. Biogeosciences 5:463-474

Clavano WR, Boss E, Karp-Boss L (2007) Inherent optical properties of non-spherical marine-like particles: from theory to observation. Oceanogr Mar Biol Annu Rev 45: $1-38$
Cole J, Findlay S, Pace ML (1988) Bacterial production in fresh and saltwater ecosystems: a cross-system overview. Mar Ecol Prog Ser 43:1-10

Duarte CM, Agustí S, Vaqué D, Agawin NSR, Jordi F, Casamayor EO, Gasol JM (2005) Experimental test of bacteria-phytoplankton coupling in the Southern Ocean. Limnol Oceanogr 50:1844-1854

Ducklow HW, Quinby HL, Carlson CA (1995) Bacterioplankton dynamics in the equatorial pacific during the $1992 \mathrm{El}$ Niño. Deep-Sea Res II 42:621-638

> Ducklow HW, Smith DC, Campbell L, Landry MR, Quinby HR, Steward GF, Azam F (2001a) Heterotrophic bacterioplankton in the Arabian Sea: basinwide response to yearround high primary productivity. Deep-Sea Res II 48: 1303-1323

Ducklow HW, Carlson CA, Church M, Kirchman D, Smith D, Steward G (2001b) The seasonal development of the bacterioplankton bloom in the Ross Sea, Antarctica, 19941997. Deep-Sea Res II 48:4199-4221

> DuRand MD, Olson RJ (1996) Contributions of phytoplankton light scattering and cell concentration changes to diel variations in beam attenuation in the equatorial Pacific from flow cytometric measurements of pico-, ultra- and nanoplankton. Deep-Sea Res II 43:891-906

Fujii M, Boss E, Chai F (2007) The value of adding optics to ecosystem models: a case study. Biogeosciences 4: 817-835

Green RE, Sosik HM, Olson RJ (2003) Contributions of phytoplankton and other particles to inherent optical properties in New England continental shelf waters. Limnol Oceanogr 48:2377-2391

Grob C, Ulloa O, Claustre H, Huot Y, Alarcon G, Marie D (2007) Contribution of picoplankton to the total particulate organic carbon concentration in the eastern South Pacific. Biogeosciences 4:837-852

Grossart HP, Kiorboe T, Tang K, Plough H (2003) Bacterial colonization of particles: growth and interactions. Appl Environ Microbiol 69:3500-3509

> Jonasz M, Fournier G, Stramski D (1997) Photometric immersion refractometry: a method for determining the refractive index of marine microbial particles from beam attenuation. Appl Opt 36:4214-4225

Katz A, Alimova A, Xu M, Rudolph E and others (2003) Bacteria size determination by elastic light scattering. IEEE J Sel Top Quant Elect 9:277-287

Kiefer DA (1984) Microplankton and optical variability in the sea: fundamental relationships. Proc SPIE 489:42-48

Knap A, Michaels A, Close A, Ducklow H, Dickson H (1994) Protocols for the Joint Global Ocean Flux Study (JGOFS) core measurements. JGOFS Rep No. 19, Reprint of the IOC Manuals and Guides No. 29, UNESCO, Paris

Li WKW, Head EJH, Harrison G (2004) Macroecological limits of heterotrophic bacterial abundance in the ocean. Deep-Sea Res I 51:1529-1540

Loisel H, Morel A (1998) Light scattering and chlorophyll concentration in case 1 waters: a reexamination. Limnol Oceanogr 32:847-858

Mitchell BG, Holm-Hansen O (1991) Bio-optical properties of Antarctic Peninsula waters: differentiation from temperate ocean models. Deep-Sea Res 38:1009-1028 V

> Morel A, Ahn Y (1990) Optical efficiency factors of free-living marine bacteria: influence of bacterioplankton upon the optical properties and particulate organic carbon in oceanic waters. J Mar Res 48:145-175

Oubelkheir K, Claustre H, Sciandra A, Babin B (2005) Biooptical and biogeochemical properties of different trophic regimes. Limnol Oceanogr 50:1795-1809 
Quan X, Fry ES (1995) Empirical equation for the index of refraction of seawater. Appl Opt 34:3477-3480

Sieburth JM, Brooks RD, Gessner RV, Thomas CD, Tootle JL (1974) Microbial colonization of marine plant surfaces as observed by scanning electron microscopy. In: Colwell RR, Morita RY (eds) Effect of the ocean environment on microbial activities. University Park Press, Baltimore, p 418-432

Simon M, Azam F (1989) Protein content and protein synthesis rates of planktonic marine bacteria. Mar Ecol Prog Ser 51:201-213

Spinrad RW, Gover H, Ward BB, Codispoti LA, Kullenberg G (1989a) Suspended particle and bacterial maxima in Peruvian coastal waters during cold water anomaly. Deep-Sea Res 36:715-733

Spinrad RW, Yentsch CM, Brown J, Dortch Q, Haugen E, Revelante N, Shapiro L (1989b) The response of beam attenuation to heterotrophic growth in a natural population of plankton. Limnol Oceanogr 34:1601-1605
Stramski D, Kiefer DA (1990) Optical properties of marine bacteria. Proc SPIE 1302:250-268

Stramski D, Kiefer DA (1991) Light scattering by microorganims in the open ocean. Prog Oceanogr 28:343-383

Stramski D, Kiefer DA (1998) Can heterotrophic bacteria be important to marine light absorption? J Plankton Res 20: $1489-1500$

Stramski D, Bricaud A, Morel A (2001) Modeling the inherent optical properties of the ocean based on the detailed composition of planktonic community. Appl Opt 40:2929-2945

Ulloa O, Sathyendranath S, Platt T, Quiñones R (1992) Light scattering by marine heterotrophic bacteria. J Geophys Res 97:9616-9629

Van de Hulst HC (1957) Light scattering by small particles. John Wiley and Sons, Chichester

Wiebe WJ, Pomeroy LR (1972) Microorganisms and their association with aggregates and detritus in the sea: a microscopic study. Mem Ist Ital Idrobiol 29(Suppl):325-352

Appendix 1. Proportion of particulate beam attenuation explained by marine heterotrophic marine bacteria with a spherical shape

The response of $c_{\mathrm{p}}$ with respect to HB was examined by plotting $C_{\mathrm{p}}$ as a function of particle cross-sectional area per unit of volume (PCSA), and by analyzing the magnitude of the average attenuation efficiency factor for HB $\left(C_{\mathrm{p}} / \mathrm{PCSA}\right)$ (Behrenfeld \& Boss 2006) (Fig. A1).

Although $C_{\mathrm{p}}$ and PCSA of HB were positively related in all studied areas (Fig. $\mathrm{A} 1 \mathrm{a}, \mathrm{C})$, the dispersion of points around the regression line of south Antarctic $\left(C_{\mathrm{p}}=2.043 \mathrm{PCSA} \pm\right.$ $0.256[1 \mathrm{SE}]+0.141 \pm 0.051)$ and non-polar $\left(c_{\mathrm{p}}=0.78\right.$ PCSA $\pm 0.16+0.02 \pm 0.02$ ) samples was remarkable. This variability along the regression line could be attributed to the influence of additional optical components affecting $c_{\mathrm{p}}$ (e.g. detritus, phytoplankton). Detritus concentration is minimal in Antarctic waters (Mitchell \& Holm-Hansen 1991); thus, phytoplankton is probably the main factor responsible for the observed poor fit between $C_{\mathrm{p}}$ and PCSA in south Antarctic waters. In low and mid latitudes, detritus and phytoplankton are probably the main particulates determining residuals between measured and estimated $C_{\mathrm{p}}$ values as a function of PCSA. The coefficient of determination $\left(\mathrm{r}^{2}\right)$ of $C_{\mathrm{p}}$ - PCSA relationships was not statistically different between south Antarctic and non-polar datasets (Fischer's $Z$ transform test, $\mathrm{p}=0.59$ ).

According to Van de Hulst (1957), $C_{\mathrm{p}}$ /PCSA should be not be greater than 3.2 when $c_{\mathrm{p}}$ variability is completely explained by the particle polydispersion under study. In our case, this premise was only true for $c_{\mathrm{p}}$ measurements of low and mid latitudes (Fig. A1d). Switching to a cylindrical bacterial shape (cylindrical-to-spherical projected area $=1.12$ ) improved $c_{\mathrm{p}}$ - PCSA functionality in south Antarctic samples and decreased $C_{\mathrm{p}} / \mathrm{PCSA}$ values even though this improvement was minor $(\sim 10 \%)$.

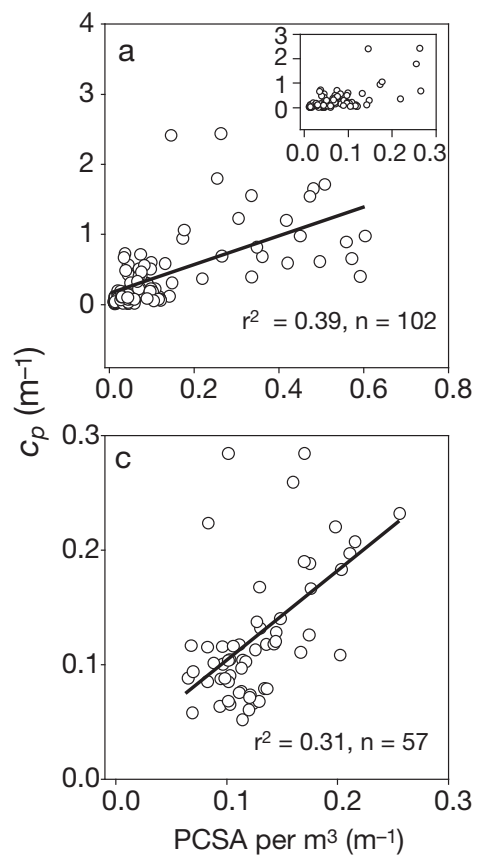

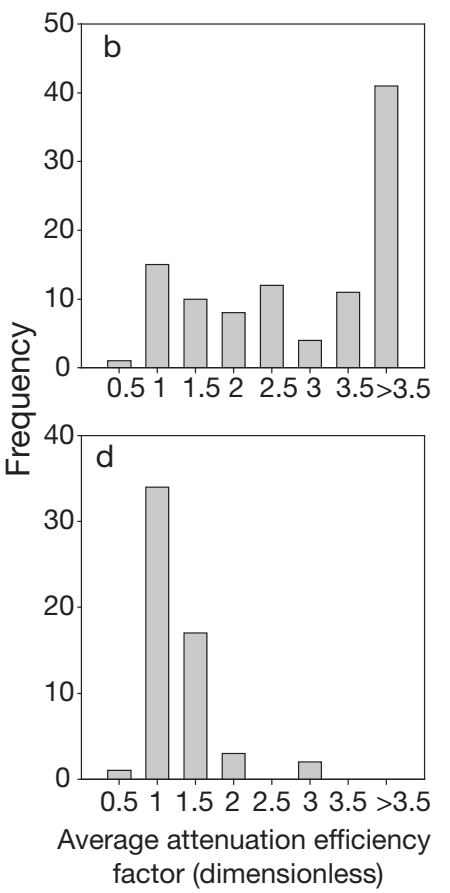

Fig. A1. Relationships between $c_{\mathrm{p}}$ and particle cross sectional area (PCSA) $(\mathrm{a}, \mathrm{c})$ and histograms of average attenuation efficiency factor $(b, d)$ for Antarctic $(\mathrm{a}, \mathrm{b})$ and non-polar surveys $(\mathrm{c}, \mathrm{d})$. Inset in (a) shows PCSA values on an $x$-axis scale between 0 and 0.3 ( $y$-axis scale, 0 to 3 ). Note that ranges of $C_{\mathrm{p}}$ and PCSA values of non-polar surveys are smaller compared with Antarctic surveys. Linear regression between $c_{p}$ and PCSA (solid line) suggest that HB was not a major optical constituent dictating $C_{\mathrm{p}}$ variability in surface marine waters of Antarctic and non-polar surveys 
Appendix 2. Variation of cell size distributions of marine heterotrophic bacteria inhabiting oceanic waters and as a function of latitude

For low and mid latitude and Antarctic samples, the probability distribution function (pdf) was computed for each bin of $d\left(\mathrm{pdf}_{i}\right)$ by normalizing the number of observations

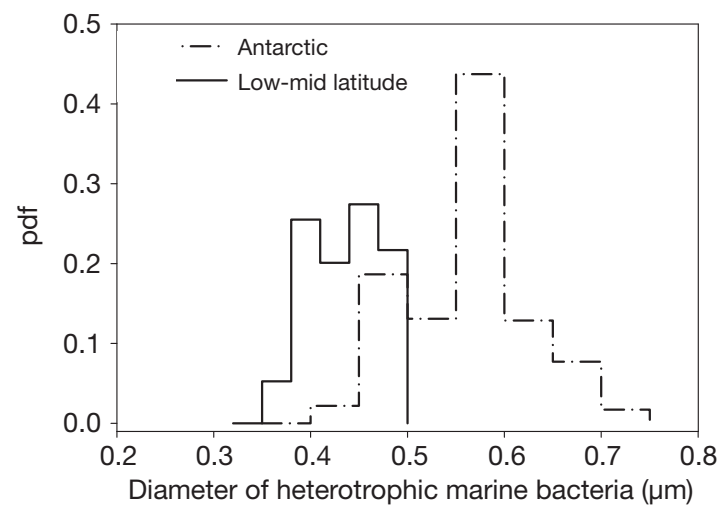

in each $d$ interval by the total number of observations of the group $\left({ }^{\mathrm{TM}} \mathrm{pdf}_{i}=1\right)$.
Fig. A2. Probability of finding different bacterial cell size ranges in oceanic domains situated at different latitudes. The diameter of heterotrophic bacteria is derived from biovolume measurements and considers cells with a spherical shape. The mode for Antarctic samples (APF, RS) is $0.55 \mu \mathrm{m}$, and for non-polar samples (EQP, ARAB) is $0.44 \mu \mathrm{m}$. Peakiness of pdf (kurtosis) is greater in Antarctic samples compared with low and mid latitude samples. APF: Antarctic Polar Front; RS: Ross Sea; EQP: equatorial Pacific; ARAB: Arabian Sea
Editorial responsibility: Rodney Forster, Lowestoft, UK
Submitted: August 19, 2008; Accepted: December 10, 2008 Proofs received from author(s): March 12, 2009 